\title{
A Program for the Preservation and Revitalization of the Languages of Russia
}

\author{
Andrej A. KIBRIK \\ Institute of Linguistics of the Russian Academy of Sciences \\ and Lomonosov Moscow State University \\ Moscow, Russia
}

\begin{abstract}
This article presents the Program for the Preservation and Revitalization of the Languages of Russia proposed by the Institute of Linguistics, Russian Academy of Sciences (the Program). The Program is based on knowledge accumulated in linguistics in domains such as linguistic diversity, language endangerment, and language preservation methods. According to a recent assessment, there are 150 to 160 languages of Russia. This number of languages, even though quite high, is manageable for a national language preservation Program. Languages are rapidly becoming extinct worldwide, and Russia is no exception to this trend. The following terms are used to categorize languages according to risk of extinction: safe languages, endangered languages, severely endangered languages, and nearly extinct languages. There are several important humanitarian and scientific reasons for engaging in language preservation. The central idea of the Program is to boost intergenerational language transmission wherever feasible. Various approaches to different language situations are envisaged, including enlightenment campaigns, language nests, and language documentation. Three necessary conditions for language revitalization include engaging local activists, administrative and financial support, and the scientific validity of the methodology. The Program's 12-year roadmap is split into three stages. There are a number of favorable factors making the Program feasible, as well as a number of potential obstacles. We have a historic opportunity to preserve languages spoken in Russia, and this is an opportunity that must be used.

Keywords: linguistic diversity, language preservation, language revitalization, documentation, intergenerational language transmission, language activism
\end{abstract}

For citation:

Kibrik, Andrej A. 2021. A Program for the Preservation and Revitalization of the Languages of Russia. Russian Journal of Linguistics 25 (2). 507-527. DOI: https://doi.org/10.22363/26870088-2021-25-2-507-527

Научная статья

\section{Программа сохранения и возрождения языков России}

\author{
А.А. КИБРИК \\ Институт языкознания РАН и МГУ имени М.В. Ломоносова \\ Москва, Россия
}

\begin{abstract}
Аннотация
Статья представляет Программу сохранения и возрождения языков народов России, предлагаемую Институтом языкознания Российской академии наук. Программа основывается на знаниях, накопленных в лингвистике в таких областях, как языковое разнообразие, угроза
\end{abstract}


исчезновения языков, методы сохранения языков. В соответствии с актуальной оценкой, в России насчитывается от 150 до 160 языков. Это количество, хотя и высокое, является обозримым для национальной Программы сохранения языков. В мире протекает быстрый процесс исчезновения языков, и Россия не стоит в стороне от этого глобального тренда. В статье используется классификация языков, включающая следующие категории: благополучные языки, языки под угрозой, исчезающие языки, языки на грани исчезновения. Имеется несколько серьезных гуманитарных и научных причин для того, чтобы заниматься сохранением языков. Центральная идея Программы состоит в том, чтобы поддержать межпоколенческую передачу языков в тех случаях, где это возможно. Рассматриваются различные подходы к разным языковым ситуациям, включая просветительские кампании, метод языковых гнезд, лингвистическая документация. Три необходимых условия, которые должны быть соблюдены в любом проекте по ревитализаии, это участие языковых активистов, административная и финансовая поддержка, научная методология. Дорожная карта Программы включает три этапа и рассчитана в целом на двенадцать лет. Отмечаются благоприятные для реализации программы факторы, а также возможные препятствия. Имеется исторический шанс предпринять усилия для поддержки языков России, и этот шанс следует использовать.

Ключевые слова: языковое разнообразие, сохранение языков, ревитализация языков, документация, межпоколенческая передача, языковой активизм

\section{Для цитирования:}

Kibrik A.A. A Program for the Preservation and Revitalization of the Languages of Russia. Russian Journal of Linguistics. 2021. Vol. 25. № 2. P. 507-527. DOI: https://doi.org/10.22363/ 2687-0088-2021-25-2-507-527

\section{Introduction}

Linguistic diversity is among the most important humanitarian legacies of humankind. Still, in the modern world, languages are rapidly becoming extinct or moving towards extinction. This process is akin to the reduction of biodiversity and definitely causes concern. The world is becoming more and more monotonous. When a language disappears, so does the whole universe that is imprinted in it. Society cannot observe language extinction with philosophical equanimity. It is impossible to force people to use minor languages but it is possible to give native speakers a chance to keep their languages alive. This is where language preservation comes in. Public attention was drawn to linguistic diversity and its endangerment when the UN announced 2019 as the International Year of Indigenous Languages. After the completion of the International Year, a decision was made to organize an International UN Decade of Indigenous Languages in 2022-2032.

These global processes and decisions fully apply to Russia. First, Russia traditionally boasts a fair amount of linguistic diversity. Second, this diversity is under significant threat. Third, Russia celebrated the International Year of Indigenous Languages by organizing many events, including several major conferences. Furthermore, at the end of 2019, a session of the Presidential Council for the Russian Language was held at which the author of this article proposed launching a national program of language preservation aimed at slowing down the process of language extinction and, possibly, reversing the process wherever possible. On March 1, 2020 a directive by President Vladimir Putin was signed that contained a number of important language-related instructions to the Government and other authorities. Among these, there was an instruction to the Government 
to provide financial, legal, and organizational support for the Institute of Linguistics $R A S$ 's Program for the preservation and revitalization of the languages of Russia. The goal of this paper is to outline the ideas and features of the Program as it looks at the current stage of preparation (March 2021).

The paper is structured as follows. Sections 2 and 3 characterize the linguistic diversity and language endangerment in Russia, respectively. Section 4 explains why language preservation is important. Section 5, which is the key section and the most extensive one, describes the Program. Section 6 provides conclusions and perspectives.

\section{The linguistic diversity of Russia}

How much linguistic diversity is there in Russia? In other words, how many languages are there? This question, on close inspection, is a difficult one to answer. The Institute of Linguistics of the Russian Academy of Sciences is currently conducting a study on this issue. This is a collective study, the main author of which is Yuri Koryakov (for its preliminary results, see Koryakov et al. 2019 and Koryakov et al. 2020). According to the assessment of this research group, there are 150 to 160 languages that can be recognized as modern languages of Russia (cf. a similar number in the title of the book by Alpatov 2000, as well as the materials of the encyclopedia Mikhalchenko ed.2016). There are several fundamental problems that stand out in many cases and affect decisions on the status of particular languages. First, there is the classic dilemma of "language vs. dialect". Second, it is important to make a reasonable distinction between genuine ("indigenous") languages of a territory and languages of relatively recent migrant populations. Third, it is often difficult to determine whether a given language is still living or is already extinct. The above cited estimate of 150 to 160 languages is based on a systematic calculation which takes into account all the relevant factors.

Russia's linguistic diversity is shown on the map (see figure 1) compiled by Yuri Koryakov. In some cases, this map shows groups of languages rather than languages per se, but one can still get a feeling for the degree of linguistic diversity found in Russia.

Is the figure " 150 to 160 " big or small? In Russian society, it is widely believed that Russia is an extremely multiethnic and multilingual country. To assess the objectivity of such assessment, it is useful to make a comparison with other countries. Indeed, compared to most European countries, the number of languages is significantly higher and, therefore, we face more complex problems than those of the developed and relatively prosperous countries of Europe. At the same time, there are many countries in the world that are much more multilingual than Russia. To make a comparison in a quantitative fashion, I use a measurement that can be called linguistic unit area, that is the ratio of the area in square kilometers to the number of languages spoken in this area. In other words, unit area is the average area per language. Table 1 shows the unit areas characteristic of seven countries of the world, including Russia. 


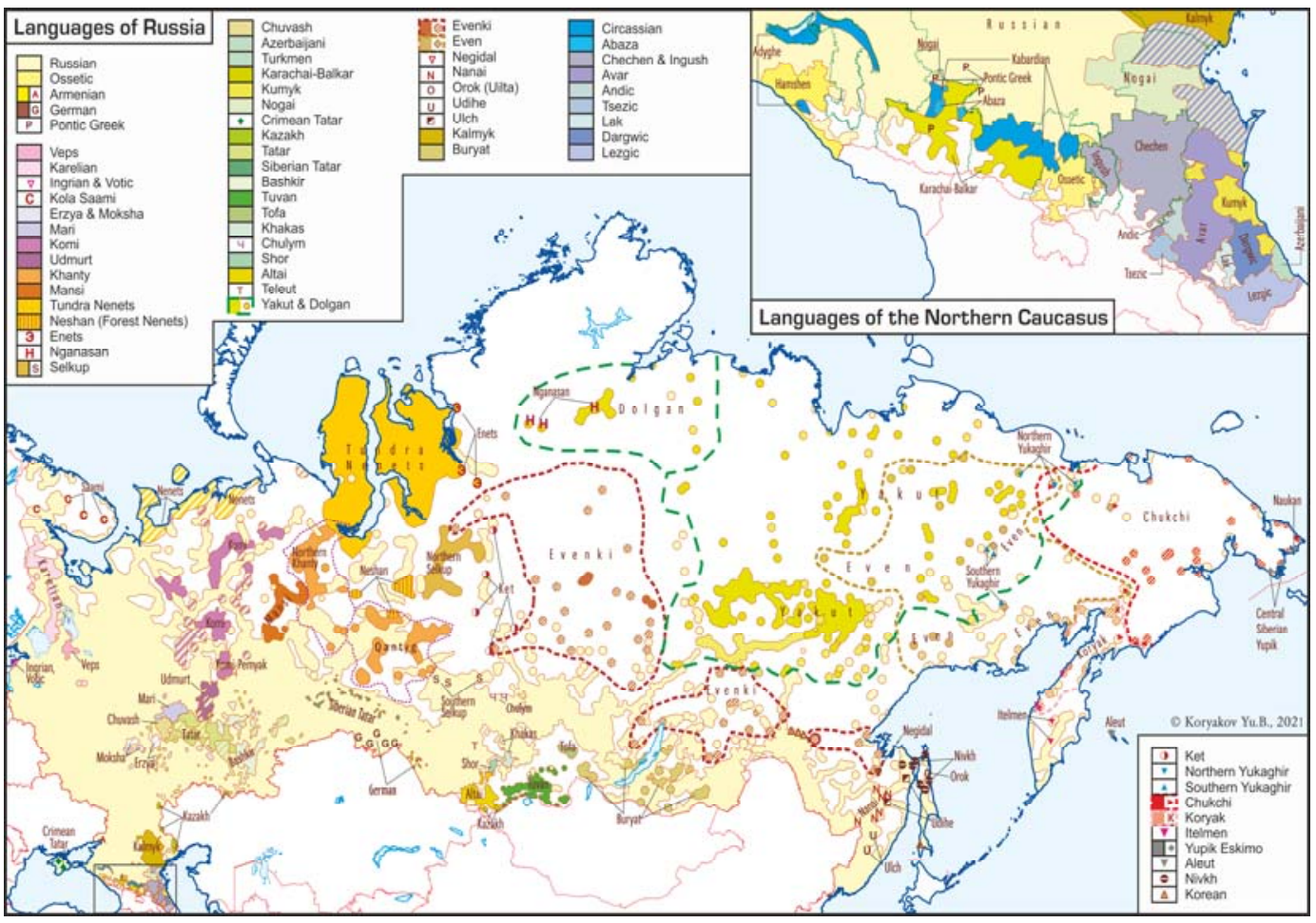

Figure 1. Languages of Russia. Compiled by Yu.B. Koryakov

Table 1. Linguistic unit area of several countries

\begin{tabular}{|l|c||c|}
\hline \multicolumn{1}{|c|}{ Country } & Number of languages $^{\mathbf{1}}$ & Unit area, $\mathbf{~ s q ~ k m ~ p e r ~ l a n g u a g e ~}^{-152}$ \\
\hline \hline Russia & 230 & 113,000 \\
\hline USA & 300 & 41,000 \\
\hline \hline China & 450 & 32,000 \\
\hline India & 700 & 7,300 \\
\hline \hline Indonesia & 500 & 2,700 \\
\hline Nigeria & 850 & 1,800 \\
\hline \hline Papua New Guinea & & 545 \\
\hline
\end{tabular}

As is clear from Table 1, all of the countries included in this comparison have a higher density of languages than Russia. For example, in the United States, one language on average accounts for about three times less territory. In Nigeria, the unit area is more than 60 times lower than in Russia, and, in Papua New Guinea, it is 200 times lower. As a result, from a global perspective, the linguistic diversity of Russia is relatively modest. This level of diversity is the result of long-term historical processes, an analysis of which is beyond the scope of this paper.

${ }^{1}$ The number of the languages of Russia is taken to be 152 in this table, in accordance with Koryakov et al. 2020. The data on the number of languages in other countries are obtained from various open sources, such as ethnologue.com and Wikipedia, and are approximate. It must be noted that the calculation criteria for other countries were different than those for Russia, and sometimes not even provided, so the comparison is tentative. 
However, in practice, the manageable level of Russia's linguistic diversity gives us a chance to propose measures aimed at the maintenance and preservation of existing diversity.

\section{Language endangerment and efforts towards language preservation}

Language extinction is a global process. There is no doubt that linguistic diversity around the world is now under significant threat. According to many forecasts (see, e.g., Austin \& Sallabank 2011), one half or a greater proportion of the estimated 7,000 languages spoken in the world today may vanish by the end of the century if current trends are allowed to continue. As with any futurology, the accuracy of forecasts is difficult to determine but the global vector is obvious: human languages are dying out with startling rapidity. Of course, languages have always died out. For example, the once widely-spoken Sumerian language was eventually supplanted by Akkadian, which also later became extinct. However, the mass disappearance of languages was triggered by the Age of Discovery, which began in the 15th century and during which Europeans subdued the entire territory of the Earth, and many ethnic groups - and, as a result, languages - were destroyed due to genocide or epidemics brought by colonizers.

Now these types of brutal eradication are no longer typical but the process of language disappearance, which began in the 15th century, is accelerating. Currently, the most significant threats to linguistic diversity are associated with globalization and related factors such as the influence of television, social media, and other means of communication, which mostly employ large dominant languages. The main mechanism of language disappearance in the modern world is the process known as language shift (Haugen 1938, Weinreich 1953): a change in the attitude of young parents who, when bringing up their newborn children, give preference to a socially prestigious language, such as English, Spanish, Russian, or Chinese, over their own ethnic (native) language. When language shift pervades a whole linguistic community, intergenerational language transmission is interrupted and it only takes a few decades for the language to become extinct (see, e.g., Fishman 1991).

From the point of view of language endangerment, Russia is no exception (see, for example, Kazakevich \& A.E. Kibrik 2007). The above-mentioned study by Koryakov et al. (2020) indicates that 15 languages of Russia became extinct during the last 150 years. The process of languages extinction is accelerating: about half of these languages were lost during the post-Soviet period (thirty years), including languages such as Sireniki Eskimo (1997), Oroch (2008) and East Mansi (2018). Unfortunately, the list of recently extinct languages is expanding. In early March 2021, the last speaker of Aleut in Russia, who lived on Bering Island, passed away (Evgeny Golovko, personal communication).

According to the assessment in Koryakov et al. 2019, 25 languages are on the verge of extinction, that is, the only people who speak them are elderly since the process of intergenerational transmission was interrupted several decades ago. This 
group of nearly extinct languages makes up $16 \%$ of all the languages of Russia; see row "Type 3" in Table 2. Perhaps even more alarming is the fact that the vast majority of the languages of Russia (about $75 \%$ ) are endangered to a certain extent (rows "Type 1A", "Type 1B" and "Type 2" taken together), while only 9\% of languages are safe (row "Type 0"). Quantitative data in Table 2 need further verification, and this will be done in the course of the Program's development, see Section 5. Results comparable to those reported in Table 2 appear in the well-known UNESCO study (Moseley ed. 2010).

Table 2. Sociolinguistic types of the languages of Russia, with a quantitative breakdown

\begin{tabular}{|l|c|c|}
\hline \multicolumn{1}{|c|}{ Sociolinguistic status (type) of language } & Number & $\begin{array}{c}\text { Share among } \\
\text { the languages of Russia }\end{array}$ \\
\hline Type 0. Safe languages & 14 & $9.2 \%$ \\
\hline $\begin{array}{l}\text { Type 1A. Endangered languages with a relatively large } \\
\text { number of speakers }\end{array}$ & 30 & $19.7 \%$ \\
\hline $\begin{array}{l}\text { Type 1B. Endangered languages with a small number } \\
\text { of speakers (definitely endangered) }\end{array}$ & 64 & $42.1 \%$ \\
\hline Type 2. Severely, or critically, endangered languages & 19 & $12.5 \%$ \\
\hline Type 3. Nearly extinct languages & 25 & $16.5 \%$ \\
\hline TOTAL & 152 & $100 \%$ \\
\hline
\end{tabular}

Public discussions on the endangerment of the languages of Russia often focus on the minority languages of the North (commonly described as the languages of the low-numbered indigenous peoples of the North, Siberia, and the Far East). It is definitely true that most of these languages are highly endangered or nearly extinct but, in fact, the trend is the same, with a certain lag, for many languages in another Russian region of high linguistic diversity, i.e., the North Caucasus, and Dagestan in particular. For example, according to the Republic of Dagestan's Minister of Ethnic Policy Tatiana Gamaley, over one half of the languages of Dagestan are seriously endangered ${ }^{2}$. Language endangerment in Dagestan is associated with economy-driven social processes: there is massive migration from mountain villages to cities and lowland settlements, with the ensuing rejection of ethnic languages and shift to Russian. Even in mountain villages, in some cases, children come to school with a better command of Russian than the local ethnic language.

Much concern is also associated with "Type 1A" of Table 2. Endangered languages with a relatively large number of speakers include most of the official, or "titular", languages of the republics in Russia. In fact, only several titular languages are safe, and that is an exception to the general rule. It may seem that the titular languages have been protected by their status all through the Soviet and postSoviet periods but, unfortunately, that status as such provides no immunity against the processes leading to language extinction; cf. Zamjatin et al. 2012, Alòs i Font 2015. Consider Kalmyk, the official language of one of the Russian republics. According to a survey conducted by Petr Bitkeev, a researcher from

${ }^{2}$ See https://tass.ru/v-strane/4632812. 
Elista, at one school in the Tselinnyj district parents of schoolchildren use Kalmyk to speak to each other $89 \%$ of the time; in contrast, schoolchildren speak Kalmyk with their parents $57 \%$ of the time, with teachers $53 \%$ of the time, with siblings $30 \%$ of the time, and with peers at school $22 \%$ of the time (Bitkeev, 2012: 9). If these data are accurate, we observe that the Kalmyk language use has dropped by a factor of four in one generation. ${ }^{3}$ Yet, at the same time, I must emphasize that the process of language extinction has been somewhat slower in Russia compared to a number of other multilingual countries. For example, consider Australia: according to McConvell \& Thieberger 2001, of the 250 aboriginal languages that existed in Australia two hundred years ago, only 90 remained alive at the beginning of the $21^{\text {st }}$ century and only 17 of those continued to be used by all age groups. The fact that the process of language eradication has not been so intensive in Russia gives us a historic chance to slow down this process if Russian society as a whole, and ethnic communities in particular, are ready to make the necessary efforts.

\section{Does language endangerment matter? Is language preservation worthwhile?}

Why should we be concerned about the process of language extinction? One might reason as follows: everything changes in this world, things come and go, and if a community or individuals wish to switch to a more prestigious language, that is their right. Indeed, no one can be forced to stick to their native language. Everyone has the right to choose their preferred means of communication and thinking, including when raising their children. Still, there are several reasons why language preservation is important.

Firstly, the disappearance of any human language is an irreparable loss for all of the humanity because each language is a special creation of human thought, culture and history, and carries cultural and cognitive characteristics uniquely imprinted in it. Secondly, linguistic identity makes up an important part of one's personal identity. Quite often, when somebody loses their linguistic identity, they experience stress, losing their connection to previous generations and to their traditional culture, and even losing an understanding of who they are. This can lead to ethnic conflict and even extremist behavior. So, the society benefits from its members adhering to their linguistic identity. Thirdly, and more generally, people prefer diversity over sameness and monotony. This has been widely recognized with respect to biodiversity, and the same applies to linguistic diversity.

Therefore, even though society cannot impose native languages on those who deliberately want to assimilate, it should still create favorable conditions for language preservation, that is, give a chance to those individuals and groups who are willing to preserve their languages. It is up to each individual and language community whether they take advantage of this opportunity or not.

${ }^{3}$ When I cited these data publicly, another colleague from Elista, Viktorija Kukanova, informed me that the actual situation with the Kalmyk language has deteriorated even further, and it has almost gone out of use. 
Linguists, as a professional group, feel particular responsibility for language preservation. Michael Krauss, one of those who were instrumental in drawing attention to mass language extinction some thirty years ago, said: "Obviously, we must do some serious rethinking of our priorities, lest linguistics go down in history as the only science that presided obliviously over the disappearance of $90 \%$ of the very field to which it is dedicated" (Krauss 1992: 10).

Thinking along similar lines, we at the Institute of Linguistics RAS believe that efforts towards the preservation of the languages of Russia must be our mission and have, therefore, proposed the Program that is described below ${ }^{4}$.

\section{The Program}

\subsection{The first step}

In the first half of 2020, a campaign was held to collect suggestions for amendments to the Russian Constitution. The Institute of Linguistics RAS proposed the following amendment: "Languages of Russia are protected by the state as the main element of the country's humanitarian legacy". It appears that our suggestion was acted upon. Article 69 of the new text of the Constitution, adopted at the referendum of July 1, 2020, includes the following formulation (my italics to emphasize elements that are particularly relevant for this article):

The state protects the cultural identity of all peoples and ethnic groups of the Russian Federation and guarantees the preservation of ethno-cultural and linguistic diversity.

This is an important statement. Linguistic diversity is thus protected by the Constitution. If linguistic diversity continues to shrink, that will mean a violation of the Constitution. This, I think, provides a foundation for our further action.

\subsection{Prerequisites}

The national Program for the Preservation and Revitalization of the Languages of Russia (hereinafter referred to as the Program) should be based on a number of prerequisites that need to be stated explicitly. These prerequisites are of a scientific nature and, at the same time, are quite easily comprehensible, even for lay persons.

First, each language is a means of natural communication, primarily through everyday speech. The use of language in educational, scientific, official and other domains is secondary to its most basic use. Therefore, even if a language has some official status, and/or is taught at school, but is not used in everyday interpersonal communication, its prospects are gloomy. The most important task in language preservation is the preservation or reinstatement of spoken everyday communication. These simple truths are often neglected in public discussions around language revival, which tend to focus on school education, written use, literacy, etc.

${ }^{4}$ An earlier and more preliminary presentation of the Program appeared in Russian in Kibrik 2020. 
Second, a person's language competence is normally formed in early childhood. We learn our native languages from our parents, in the family. This is another important point that somehow gets forgotten or ignored in language policy discussions. Where the process of intergenerational transmission has been interrupted or reduced, it needs to be restored, otherwise language revival is unlikely. Once again, it is counterproductive to focus all efforts exclusively on school education. Productive learning of ethnic languages at school is possible only if young children enter school having previously acquired the language from their parents or other family members. If that is not the case, school efforts will largely be in vain.

Third, it is important to realize that our urge to use ethnic languages is fully compatible with the nationwide use of Russian. Bilingualism and multilingualism are normal human conditions. Most of the world's ethnic groups have been multilingual for centuries, and that factor by itself did not undermine their identity. Moreover, currently there is scientific evidence that multilingualism can be cognitively beneficial for aging people, delaying the onset of dementia and Alzheimer's disease; see for example Craik et al. 2010., Gold 2015. All in all, in modern Russia, there is no need for an exclusive choice between an ethnic language and Russian as the national language since anyone can acquire and speak more than one language. To paraphrase Olga A. Kazakevich, the Russian language must be acquired by children along with, and not instead of, their ethnic tongues (cf. Kazakevich 2008). In other words, acquisition of ethnic languages is compatible with the simultaneous acquisition of Russian.

The fourth prerequisite is of a different nature and is associated with the international experience of the last 50 years. Numerous countries that had previously been particularly "efficient" in eradicating minority languages switched to preserving those same languages around the end of the 1960s. This experience is not always successful as the task of language revitalization is difficult. Still, there are important positive examples. We must analyze previous experience in detail, keeping in mind two goals: first, not to repeat other people's mistakes and, second, to embrace all the effective methods that have been developed around the world, as well as in Russia.

\subsection{The central idea of the Program and the main approaches}

The central idea of the Program is to create conditions for natural transmission of language competence from the older generations to young children of the pre-school age acquiring their first language(s). In this section, I outline the main approaches and methods under consideration which will be finalized in the course of the Program's development. These approaches vary depending on the type of language situation.

Table 3 shows a rough classification of language situations, largely following what is already familiar from Table 2. There are two differences from the list of types found in Table 2. First, Type 0 (safe languages) is not included in Table 3, as 
these languages fall beyond the Program's scope. Second, Types 1A and 1B as cited in Table 2 are merged into one type in Table 3, i.e., Type 1 "endangered languages" without breakdown for the number of speakers. The latter point needs some comment. Type 1A languages that have a greater number of speakers are mostly "titular" languages of the republics. As was argued above, the titular status does not, in itself, provide sufficient prestige for native speakers. Larger languages have some advantages over minor 1B languages (such as Abaza or Veps), just because of the quantitatively higher probability of preservation but, in general, the two situations are similar and require similar handling.

Table 3. Sociolinguistic situations and the corresponding approaches

\begin{tabular}{|l|l|l|}
\hline \multicolumn{1}{|c|}{$\begin{array}{c}\text { Sociolinguistic status } \\
\text { (type) of language }\end{array}$} & $\begin{array}{c}\text { Condition of intergenerational } \\
\text { transmission }\end{array}$ & \multicolumn{1}{|c|}{ The most obvious approach } \\
\hline $\begin{array}{l}\text { Type 1. Endangered } \\
\text { languages }\end{array}$ & Not completely interrupted & $\begin{array}{l}\text { Enlightenment: changing social } \\
\text { practices, increasing the prestige of } \\
\text { the language, first of all, in everyday } \\
\text { communication }\end{array}$ \\
\hline $\begin{array}{l}\text { Type 2. Severely, } \\
\text { or critically, endangered } \\
\text { languages }\end{array}$ & Interrupted recently & Language nests \\
\hline $\begin{array}{l}\text { Type 3. Nearly extinct } \\
\text { languages }\end{array}$ & $\begin{array}{l}\text { Interrupted a long time ago, } \\
\text { only elderly speakers remain }\end{array}$ & Urgent documentation \\
\hline
\end{tabular}

As is clear from Table 3, different approaches are envisaged for different sociolinguistic types of language/language situations. In the case of Type 1 languages, they continue to be passed on to children in some families, and what is needed is the reinforcement of this process and its extension to a wider range of families. That is achievable by relatively "cheap" methods, such as: targeting a change in the mentality and in the practices of young parents, enlightening young parents and campaigning for the use of ethnic languages, campaigning for the use of ethnic languages, spreading awareness of the fact that multilingualism is a normal human ability, encouraging young parents who speak the language to pass it on to newly born children, and developing active bilingualism. All that may be effective in changing attitudes and family language policies (see, e.g., Macalister \& Mirvahedi eds. 2017, Smith-Christmas 2016 on family language policies). An important role belongs to the creation of electronic resources for certain languages, which positions these languages as modern and relevant. Such electronic resources may include websites, mobile applications, or games employing minority languages; some resources of these kinds have already been created by language activists, and their results will be used in the Program. A full battery of methods for Type 1 languages is to be formulated in the course of the Program development. Such methods are not easy to develop and implement but the situations with subsequent categories of languages are still more complicated.

In the case of Type 2 (for example, Nanai or Koryak), parents of young children do not speak the ethnic language, but the older generation still do. In the 
recent decades, the language nest method was developed. Under this method, young children spend a substantial amount of time in a nursery-type environment in the company of caregivers who are language speakers of their grandparents' generation. In this environment, children acquire the language in a natural way. In this case language competence is transmitted, so to speak, over the parents' heads, from the grandparents' generation to the grandchildren. This method is more laborintensive than those mentioned in the previous paragraph. The language nest method, which was first developed in New Zealand (see King 2001), proved effective and was applied in other countries as well; cf. a remarkable example of Inari-Saami in Finland, where, during the past twenty years, a large number of children learned the ethnic language in language nests (Pasanen 2010). In the case of Inari-Saami, in a very small ethnic group numbering just a few hundred persons whose language had virtually gone out of use, a whole new generation of children grew up who speak it again after an interruption that lasted decades. Nothing prevents us from trying to reproduce this kind of sociolinguistic miracle in some locations in Russia. In fact, some language nests have already been established in several locations in Russia, including Karelia and Taimyr. Apart from language nests, there are other methods as well, such as master-apprentice pairs (Hinton 2001). Additional methods may be developed and introduced.

Finally, Type 3 languages are on the verge of extinction, as only a small number of elderly speakers are still living. Examples of languages in this group are Votic or Orok. This situation is, of course, the most problematic as regards preservation prospects. For Type 3 languages, the most urgent efforts must be directed towards linguistic documentation while it is still possible (see, e.g., Woodbury 2003). I should note that attempts at language revitalization are sometimes even made for completely extinct languages, for example, for the Cornish language in England (Korolev 2000). The Cornish language became extinct in the 18th century but was revived by activists and has recently reached several hundred or even several thousand native speakers. However, it would be inappropriate to set such ambitious tasks under current Russian conditions.

Table 3 only specifies the most obvious approach to each particular language situation. On the ground, more flexibility will be required. For example, the approaches mentioned for Type 1 languages may be extended to some Type 2 languages as well, and so forth. It may be possible to propose a somewhat more nuanced strategy, in which the correspondence between language situations and methods is not one to one, as suggested by Table 3, but more flexible correspondences are allowed. Table 4 below offers a sketch of this kind of flexible strategy based on an age model of language situations. In this model, a decade is used as the minimum step. For example, ages 25-34 are rounded to 30 . Accordingly, three possible ages of parents are considered: 20,30, and 40. The table shows the situation for a child who is 1 or 2 years old in 2021 . The three approaches introduced in Table 3 are marked in the three rightmost columns of Table 4, where it is indicated whether they are to be used as a priority approach or as an additional approach. 
Table 4. Sociolinguistic situations and the corresponding approaches: A flexible strategy

Shading indicates: \begin{tabular}{l|l} 
priority approach & additional approach
\end{tabular}

\begin{tabular}{|c|c|c|c|c|c|c|c|}
\hline 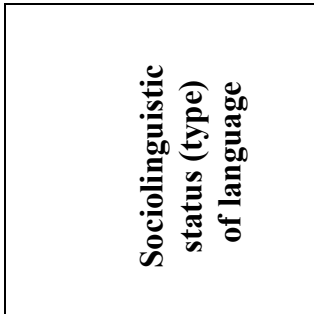 & 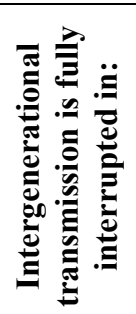 & 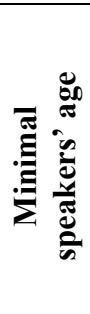 & 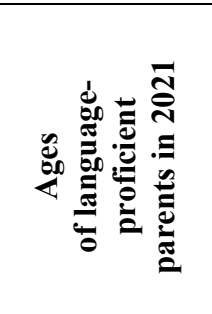 & 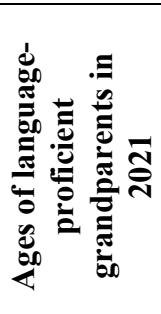 & 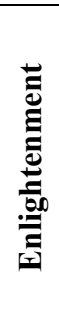 & 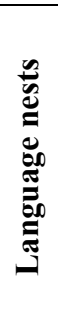 & 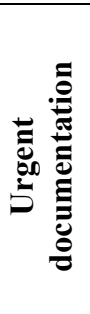 \\
\hline $\begin{array}{l}\text { Type 1. Endangered } \\
\text { languages }\end{array}$ & 2031 & 0 & - & - & & & \\
\hline \multirow{5}{*}{$\begin{array}{l}\text { Type } 2 . \text { Severely, or } \\
\text { critically, endangered } \\
\text { languages }\end{array}$} & 2021 & 0 & 20-40 (i.e. all) & $40-80$ & & & \\
\hline & 2011 & 10 & 20-40 (i.e. all) & $40-80$ & & & \\
\hline & 2001 & 20 & 20-40 (i.e. all) & $40-80$ & & & \\
\hline & 1991 & 30 & $30-40$ (not all) & $40-80$ & & & \\
\hline & 1981 & 40 & 40 (few) & $40-80$ & & & \\
\hline \multirow{3}{*}{$\begin{array}{l}\text { Type } 3 \text {. Nearly extinct } \\
\text { languages }\end{array}$} & 1971 & 50 & no & $50-80$ & & & \\
\hline & 1961 & 60 & no & $60-80$ & & & \\
\hline & 1951 & 70 & no & $70-80$ & & & \\
\hline
\end{tabular}

You can see in Table 4 that under this flexible strategy "enlightenment" is extended to some of the Type 2 languages as one of the main approaches; that is appropriate when all of the new parents still know the ethnic language but, if no effort is applied, opt for the exclusive use of the dominant language when bringing up newborn children. Likewise, other correspondences between the language situations and the methodological approaches are less rigid than what was posited in Table 3. A certain approach can be used in a variety of situations and, in specific situations, several approaches may be combined.

As was stated above, the Program is, first and foremost, concerned with language acquisition in early childhood, wherever possible. For the sake of language revitalization, of course, further efforts are necessary, including in school language education and other domains. However, all these further efforts are relevant only if a particular language continues to be learned by children and, therefore, has prospects for survival. Also, issues such as school education, literacy, writing systems, etc., are being taken care of to a substantial extent even now. In view of the above, I do not discuss these other issues in this paper.

\subsection{Components of the Program}

Language revitalization is only possible if three necessary conditions are met: local activists being engaged, administrative and financial support, and the scientific validity of the methodology. These are the three pillars on which any revitalization project must rest. All three conditions must be satisfied in the Program. Administrative and financial support was originally assigned in the President's directive. Methodology will be worked out by professional staff that will be hired to develop the Program. This work will involve an analysis of the best 
practices in the world and their adaptation to the conditions in Russia. Language activists are an emergent social group in the present-day Russia who are willing to devote a substantial part of their time and careers to language work. Among other things, activists are expected to assist in creating language nests and in ensuring interaction between native speakers and children. If a country-wide network of language activists is created and supported under the auspices of the Program, a necessary synergy between linguists, activists, and the communities will be attained.

Building upon the discussion above in this section and in the previous section, I should mention a number of other important directions to be developed in the framework of the Program:

- Scientifically grounded and state-supported social advocacy for linguistic diversity, as well as for cultural and cognitive advantages of early bilingualism and multilingualism.

- A system of state-funded cultural and linguistic centers, recruiting speakers of the older generation and putting them together with young children.

- A system of measures of organizational and financial support for local language activists and native speakers, possibly via non-profit organizations.

- A set of teaching materials for language activists that can be applied to various language situations.

- Targeted support of the media using indigenous languages.

- Creation of the linguistic landscape in local languages, including road signs, announcements, ads, etc. This applies not only to the titular languages of the republics in Russia but also to minority languages spoken in particular areas.

\subsection{Roadmap of the Program}

At the Institute of Linguistics RAS, we have designed a 12-year roadmap for the Program. The roadmap involves three stages, the first two are brief and the third one is extensive:

- Stage I, 2021: preliminary work on the Program;

- Stage II, 2022: detailed development of the Program;

- Stage III, 2023-2032: implementation of the Program.

By the end of 2022, the Program must be worked out and ready for implementation in numerous selected sites across Russia. The first two stages are of a methodological nature and can be implemented by a special unit formed within the Institute of Linguistics RAS assigned a clear practical task. Stage III is the main stage of the Program and is conceived of as a nationwide project to be carried out by hundreds of cultural-linguistic centers engaged in the on-the-ground work aimed at language revitalization at the local level. This can be called a genuine people's project for it goes beyond academia. Stage III must be managed by a specialized organization which, I hope, can be set up for this goal. This organization must work under the scientific-methodological supervision of the Institute of Linguistics RAS, and in coordination with other interested research and higher education institutions. 
The Institute of Linguistics RAS has prepared detailed economic assessments for Stages I and II of the Program. We anticipate that the funding of Stage I will start shortly.

\subsection{Favorable factors}

Is the idea of developing and implementing the Program realistic? There are several factors that make me optimistic. First, as was argued in Section 2, the number of languages of Russia is manageable. The range of languages requiring attention is wide but not boundless, and such a large country can potentially cope with supporting them all.

Second, as was mentioned in Section 3, the specific situation in Russia is that only a small proportion of its languages have vanished completely while a majority of them still exist. We have a historic opportunity to do something right now towards their revitalization.

Third, as was discussed in Sections 5.2 and 5.3, over the past half century a lot of experience has been accumulated around the world, both positive and negative. This means that the Program will not be developed from scratch but relying on an analysis of the experience of other countries, as well as existing experience in Russia. If such an analysis is carried out, one can avoid repeating past mistakes and elaborate proven techniques.

Fourth, as was pointed out in Section 5.4, we may rely on the energy and commitment of language activists and activist groups that have spontaneously appeared in many places across Russia.

Finally, I assume that we may take advantage of the highly centralized nature of the Russian state. If the coordinating center of the Program develops efficient, viable and flexible methods, these can be transferred to particular locations and local authorities may be required to implement them.

\subsection{Potential obstacles and risks}

When planning an enterprise as extensive as the Program, one must definitely think in advance about potential obstacles and risks involved. In this section, I address the main factors that may hinder the implementation of the Program.

First of all, there are several popular misconceptions that need to be dealt with. In particular, in the public consciousness, knowledge of minority languages is often associated with poverty, marginality and ignorance, while the lack of such knowledge is, on the contrary, associated with economic well-being. Such an association is not based on rational grounds, and can only be dispelled by systematic outreach activities, education and public enlightenment.

Another popular misconception is the "myth of monolingualism" (Olga A. Kazakevich's expression). Quite often, young parents, as well as other members of the general public, presume that an individual has an exclusive choice between Russian and an ethnic language. A public campaign is required to explain that no 
such choice is necessary, as any normal individual, including small children, may have command of more than one language.

Very salient is still another fallacy of public consciousness: confusion of language and rules of orthography. It must be explained that language is, first and foremost, a system of spoken interpersonal communication that emerges in early childhood, while writing in general and rules of writing in particular are secondary and, in fact, very distant from the basic life forms of language. Currently, there are fierce battles around the graphical systems of specific languages. Of course, solutions in the field of alphabets and graphics are important and interesting but they are not directly related to the essence of language as a means of interpersonal communication or to the need for language acquisition in early childhood.

In connection with the previous point, a discussion of language issues often triggers imminent thoughts about schooling. School is important, indeed. However, from times immemorial languages were passed down from generation to generation in oral form, without the participation of schools. Neither school, nor writing alone can guarantee the survival of languages; they can only serve a subsidiary role, and this needs to be explained via educational campaigns.

When a language undergoes attrition, which is often the case with endangered languages, it can be revitalized in a form that is somewhat different from its original, traditional condition. Only a modified or simplified version of the language may be feasible for new speakers. Efforts of new speakers to master the language may be hindered by an attitude of older speakers' known as linguistic purism: the idea that only the authentic form of the language is valuable. Sometimes older speakers even ridicule young speakers for not talking "correctly", thereby demotivating them from learning the language at all. It is important to realize that all languages change over time, and that, of course, applies to endangered languages as well.

Ethical standards must be observed in working with language communities. Language revitalization cannot be imposed upon a community. Views on this subject may differ, and some individuals may object to revitalization projects, especially those coordinated from the outside. People working with communities need cultural sensitivity and to refrain from simplistic and universalist attitudes towards people's linguistic rights. (On ethics in linguistic work see Tsunoda 2013: Chapter 12; Maryniak et al. 2021.)

There are also organizational risks that can disrupt the implementation of the Program. For example, problems were experienced in some cases where language activists tried to establish language nests in kindergartens, with elderly native speakers being engaged as language instructors. Such native speakers had, as a rule, been involved in traditional activities such as reindeer herding throughout their lives, whereas in the kindergarten they were suddenly required to acquire a diploma in pedagogical education. Such cases, of course, completely invalidate the very idea of the Program: in order to transmit language knowledge to young children, one simply needs to be a proficient language speaker rather than a diploma holder. These kinds of risks are of a legal nature, and ways to neutralize them must be sought. 


\subsection{Further considerations}

A few other important problems need to be considered in relation to the Program. One is that many languages have regional varieties or dialects that are very different from each other. Sometimes these differences can hinder free understanding between native speakers of different varieties. For example, this concerns dialects of Evenki spread across huge distances in Siberia. Still more acute is the situation with the so-called dialects of Dargwa in Dagestan which, according to linguistic criteria, are in fact different languages (Koryakov 2021). It must be understood that it is the local variety of the language that needs to be preserved. Imposing a dialect from a different area or a literary standard based on a different dialect upon the population of a locality where it is not used may not just be less than optimal - it may even be counterproductive.

Another problem is related to the languages of old diasporas. Languages such as Armenian, Greek, and German have been spoken in Russia for centuries, and, in many cases, Russia-based local varieties have developed that are very different from the language forms currently used in the respective countries. These kinds of languages are indistinguishable from the "indigenous" languages of Russia and are included in the list of the languages in Koryakov et al. 2020. Old diaspora languages deserve support within the framework of the Program. It makes sense to preserve them in Russia in the form of their traditionally established local varieties.

A final difficulty that I would like to mention here is associated with the problematic term "native language", including its use in the school context. Suppose a child has learned Russian as his/her first and only language. In this case, the language associated with the ethnic group to which the child belongs cannot be called this child's native language. This language is almost foreign to $\mathrm{him} / \mathrm{her}$, when s/he receives lessons of the "native language". Another awkward situation takes place if a child comes to school speaking a local variety of the language but is presented with textbooks of the "native language" using a noncomprehensible literary norm based on a completely different dialect. These kinds of situations have been quite common in schools throughout the Soviet and postSoviet periods, and they must be considered when developing practices of language preservation under the Program.

\section{Conclusions and perspectives}

In this paper, I have presented the Program for the Preservation and Revitalization of the Languages of Russia proposed by the Institute of Linguistics RAS and supported by the President's directive. In order to preserve existing linguistic diversity, one needs to take special measures. Undoubtedly, if nothing is done, the process of language extinction will continue and will accelerate. The proposed Program is aimed at preserving linguistic diversity and at slowing and, where possible, reversing, the process of language extinction.

The Program is based on the knowledge accumulated in linguistics in domains such as linguistic diversity, language endangerment, and language preservation 
methods. The central idea of the Program is to boost intergenerational language transmission wherever feasible. I have presented various approaches to different language situations, the components of the Program, the proposed roadmap, as well as favorable factors and potential obstacles. Methodological approaches, such as public advocacy for multilingualism and language nests, were introduced. In those instances when language revitalization is unlikely due to the advanced age of the remaining speakers, the Program focuses on linguistic documentation.

The Program is a part of a wider effort currently being undertaken in Russia. The President's directive of March 1, 2020 set the task of forming a consistent language policy for Russia. (See Spolsky 2004 for a general introduction to the field of language policy.) A document entitled "The Conception of Language Policy" must be created. National language policy is a system of principles guiding the use and development of languages in the country. The expectation is that such a document will serve as a template for more specific legislative acts related to the functioning of languages. The document must combine two priorities: unity on the basis of Russian as the national language and respect for the linguistic diversity of Russia. The tenets of the Program, as described in this paper, support the feasibility of such a combination. It is important to point out that the observance of the citizens' language-related rights is a factor of stability and unity. In contrast, in many post-Soviet countries we observe that the violation and oppression of people's language-related rights lead to unrest and radicalization.

In the discussion above, there was no space for addressing the functional variation of languages. In fact, just as it is beneficial to keep and develop whole languages, it is also beneficial to keep and develop functional domains in which a language can be used. In particular, at least with respect to languages of Russia with greater numbers of speakers, such as the titular languages of the republics, it is desirable to promote their use as languages of science and higher education. In this connection I would like to mention the XXI International Congress of Linguists that is going to take place in the summer of 2023 in Kazan (Republic of Tatarstan, Russia) and is organized by the Kazan Federal University and the Institute of Linguistics RAS. Information about the congress is available in three languages: English, Russian, and Tatar. Figure 2 illustrates parts of the announcement appearing on the CIPL (Comité International Permanent des Linguistes) website in English and in Tatar. By publicizing congress materials in Tatar, we promote the variety of functional domains in which this language operates.

A reader may ask why the Program is limited to the languages of Russia. Indeed, linguists from the institute study many different languages of various continents and regions, including Africa, America, South and South-East Asia, etc. There are numerous endangered languages in those areas as well. The answer to the question is that we are guided by the principle of direct responsibility. The institute is funded by the Russian state and must firstly address the languages of its home country. At the same time, I believe that, if the experience with the Program succeeds, it can be extended to other countries. The initial candidates for such 
extension would be countries and territories with historical links to Russia but any other countries would be welcome to use the results of the Program.

\begin{tabular}{r|r} 
Next venue & $\begin{array}{r}\text { International Congress of Linguists, ICL21, in Kazan, } 25 \text { June - } 2 \text { July } 2023 \\
\text { Back }\end{array}$ \\
Russian and Tatar version below
\end{tabular}

\begin{abstract}
The Executive Committee of Comité International Permanent des Linguistes, CIPL, announces that the upcoming International Congress of Linguists, ICL21, will take place in Kazan (Tatarstan, Russia) from 25 June to 2 July 2023. ICL is the world congress of linguists and started with the First International Congress of Linguists in the Hague (the Netherlands) in 1928, at which conference CIPL was founded.
\end{abstract}
ICL21 will be jointly organised by Kazan Federal University and the Institute of Linguistics of the Russian Academy of Sciences in Moscow.
21 Халыкара тел белгечләренең ICL конгрессы, Казан шәһәре, 25 июнь - 2 июль, 2023 ел

\begin{abstract}
Халыкара тел белгечләре комитетының башкарма комитеты (CIPL - Comité International Permanent des Linguistes) игълан итүенчә, алдагы 21 Халыкара тел белгечләренең ICL конгрессы Казанда (Россия Федерациясе, Татарстан Республикасы), 2023 нче елның 25 июнь - 2 июль аралыгында узачак. ICL - дөньякүләм тел белгечләре конгрессы, аңа нигез 1928 нче елда, Нидерландның Гаага шәһәрендә, Беренче халыкара тел белгечләре конгрессында салынган - CIPL шул вакытта оешкан.

ICL21 конгрессын Казан федераль университеты һәм Россия фәннәр академиясенең тел белеме Институты (Мәскәү) оештырачак.
\end{abstract}

Figure 2. Announcements about the International Congress of Linguists in English and in Tatar

To conclude, I would like to reiterate that we have a historic opportunity to undertake the effort of maintaining languages still spoken in Russia. This effort is supported by the Russian state, and there are a number of factors favoring this opportunity. This chance must be used.

(C) Andrej A. Kibrik, 2021

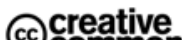
@ceative

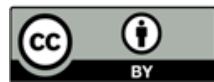

This work is licensed under a Creative Commons Attribution 4.0 International License https://creativecommons.org/licenses/by/4.0/

\title{
Acknowledgements
}

I would like to express my sincere gratitude to Andrey Shluinsky who actively participated in brainstorming the Program, as well as to all colleagues who discussed particular aspects of the Program with me. Both Andrey Shluinsky and Ekaterina Gruzdeva read a 
preliminary version of this paper and provided valuable comments. The paper benefited from numerous suggestions given by the journal's reviewers. I thank all of these colleagues for their input. I am very grateful to the Department of History and Philology of the Russian Academy of Sciences that assisted substantially in promoting the Program. I also thank Alexander Sharakshane and Vincent Skowronski who helped with the English translation of this paper. Of course, I alone am responsible for the entire content of the article.

\section{REFERENCES}

Alòs i Font, Hector. 2015. Issledovanie jazykovoj situacii v Chuvashskoj Respublike. [A study of language situation in the Chuvash Republic.] Cheboksary: Chuvashskij gosudarstvennyj institut gumanitarnyh nauk. (In Russ.)

Alpatov, Vladimir M. 2000. 150 jazykov i politika. 1917-2000: Sociolingvisticheskie problemy SSSR $i$ postsovetskogo prostranstva. [150 languages and politics. 1917-2000: Sociolinguistic problems of the USSR and the post-Soviet space.] Moscow: Kraft. (In Russ.)

Austin, Peter K., \& Julia Sallabank. 2011. Introduction. In Peter K. Austin \& Julia Sallabank (eds.), Cambridge Handbook of Endangered Languages, 1-24. Cambridge: Cambridge University Press.

Bitkeev, Petr C. 2012. Osnovnye polozheniya programmy "Zhivoj yazyk" [The main provisions of the "Language alive" program] Materialy III Mezhdunarodnoj nauchnoprakticheskoj konferencii "Problemy funkcionirovaniya $i$ razvitiya yazykov $v$ polilingval'nom prostranstve” (Elista, 7-9.10.2011), 8-13. (In Russ.)

Craik, Fergus I. M., Ellen Bialystok \& Morris Freedman. 2010. Delaying the onset of Alzheimer disease: Bilingualism as a form of cognitive reserve. Comparative Study Neurology 75(19). 1726-9. DOI: 10.1212/WNL.0b013e3181fc2a1c.

Fishman, Joshua. 1991. Reversing language Shift: Theory and Practice of Assistance to Threatened Languages. Clevedon, Multilingual Matters.

Gold, Brian T. 2015. Lifelong bilingualism and neural reserve against Alzheimer's disease: a review of findings and potential mechanisms. Behavioral Brain Research 281. 9-15. DOI: 10.1016/j.bbr.2014.12.006.

Haugen, Einar. 1938. Language and Immigration. Norwegian-American Studies and Records, 10. $1-43$.

Hinton, Leanne. 2001. Language revitalization: An overview. In Leanne Hinton \& Ken Hale (eds.), The green book of language revitalization in practice, 1-18. New York: Academic Press.

Kazakevich, Olga A. 2008. Podderzhka malykh jazykov s pomoshch'ju informacionnokommunikacionnykh tekhnologij: zarubezhnyj opyt. [Maintenance of minority languages with the help of information and communication technologies: international experience.] Predstavlenie jazykov Rossii $i$ stran SNG v rossijskom segmente Interneta. Sbornik dokladov seminara Rossijskogo komiteta Programmy UNESCO - Informacija dlja vsekh i Mezhregional'nogo centra bibliotechnogo sotrudnichestva v ramkakh Mezhdunarodnoj konferencii EVA 2007, 15-26. Moscow: Mezhregional'nyj centr bibliotechnogo sotrudnichestva. http://www.ifapcom.ru/365/528 (In Russ.)

Kazakevich, Olga A. \& Aleksandr E. Kibrik. 2007. Language endangerment in the CIS (Chapter 11). In Matthias Brenzinger (ed.) Language Diversity Endangered. Trends in Linguistics. Studies and Monographs 181, 233-262. Berlin; New York: Mouton de Gruyter. 
Kibrik, Andrej A. 2020. Sokhranenie jazykovogo raznoobrazija Rossii: kontury programmy [Preservation of linguistic diversity in Russia: Contours of the program]. Sociolinguistics 1, 17-28. http://sociolinguistics.ru/en/436-2/ (In Russ.)

King, Jeanette. 2001. Te kōhanga reo: Māori language revitalization. In Leanne Hinton \& Ken Hale (eds.), The green book of language revitalization in practice, 119-128. New York: Academic Press.

Koryakov, Yuri B. 2021. Darginskie jazyki i ix klassifikacija [Dargwa languages and their classification]. In Timur A. Maisak, Nina R. Sumbatova, \& Yakov G. Testelets (eds.), Durqasi xazna. A collection of papers for the $60^{\text {th }}$ anniversary of R.O. Mutalov, 139-154. Moscow: Buki Vedi, 2021 (In Russ.)

Koryakov, Yuri B., Tatiana B. Agranat, Maria A. Goryacheva, Anna V. Dybo, Olga A. Kazakevich, Andrej A. Kibrik, Olesya V. Khanina, Andrey B. Shluinsky. 2019. Jazyki Rossii. [Languages of Russia.] Available at: http://jazykirf.iling-ran.ru/list_2019.shtml (In Russ.)

Koryakov, Yuri B., Tatiana B. Agranat, Maria A. Goryacheva, Anna V. Dybo, Olga A. Kazakevich, Andrej A. Kibrik, Olesya V. Khanina, Andrey B. Shluinsky. 2020. Jazyki Rossii. [Languages of Russia.] Available at: http://jazykirf.iling-ran.ru/ list_concept2020.shtml (In Russ.)

Krauss, Michael E. 1992. The world's languages in crisis. Language $68(1)$. 4-10. doi:10.1353/lan.1992.0075

Macalister, John, \& Seyed Hadi Mirvahedi (eds.) 2017. Family Language Policies in a Multilingual World: Opportunities, Challenges and Consequences. New York \& London: Routledge.

Maryniak, Joanna, Justyna Majerska-Sznajder, Tymoteusz Król. 2021. Ethical Aspects and Cultural Sensitivity in Language Revitalization. In Olko, Justina \& Julia Sallabank (eds.) Revitalizing Endangered Languages: A Practical Guide, 49-59. Cambridge: Cambridge University Press.

McConvell, Patrick \& Nicholas Thieberger. 2001. State of Indigenous languages in Australia 2001. Department of the Environment and Heritage.

Mikhalchenko, Vida Ju (ed.). 2016. Jazyk i obshchestvo. Enciklopedija. [Language and society. Encyclopedia.] Moscow: Azbukovnik. (In Russ.)

Moseley, Christopher (ed.). 2010. Atlas of the World's Languages in Danger, 3rd ed. Paris, UNESCO Publishing. http://www.unesco.org/culture/en/endangeredlanguages/atlas

Pasanen, Annika. 2010. Revitalization of Inari Saami: reversal language shift in changing speech community [PPT document]. Retrieved from SlideShowes Website: http://slideshowes.com/doc/351323/revitalization-of-inari-saami--reversal-languageshift-in.

Smith-Christmas, Cassie. 2016. Family Language Policy: Maintaining an Endangered Language in the Home. Palgrave MacMillan.

Spolsky, Bernard. 2004. Language policy. Cambridge: Cambridge University Press.

Tsunoda, Tasaku. 2013. Language Endangerment and Language Revitalization: An Introduction. Berlin \& New York: Mouton de Gruyter.

Weinreich, Uriel. 1953. Languages in Contact. Findings and Problems. New York: Linguistic Circle of New York.

Woodbury, Anthony C. 2003. Defining documentary linguistics. In Peter Austin (ed.), Language Documentation and Description 1: 35-51. London: SOAS. https://www.academia.edu/26417773/Woodbury_Anthony_C_2003_Defining_document ary_linguistics_In_Peter_Austin_ed_Language_Documentation_and_Description_1_35_ 51_London_SOAS 
Zamjatin, Konstantin, Annika Pasanen \& Janne Saarikivi. 2012. Kak i zachem sokhranjat' jazyki narodov Rossii? [Why and how to protect the minority languages of Russia?] Helsinki: POGA. (In Russ.)

\section{Article history:}

Received: 16 March 2021

Accepted: 15 May 2021

\section{История статьи:}

Дата поступления в редакцию: 16 марта 2021

Дата принятия к печати: 15 мая 2021

\section{Bionote:}

Andrej A. KIBRIK graduated from Lomonosov Moscow State University in 1984 and has been working at the Institute of Linguistics of the Russian Academy of Sciences since then. Currently he is Director of the Institute as well as Professor at Lomonosov Moscow State Uiniversity. He has published on topics such as language and cognition, spoken and written discourse, multimodality, linguistic diversity, theoretical functional linguistics, field linguistics, sign languages, Native American (particularly Athabaskan) languages, languages of Russia, Russian grammar, and language policy. He has been a member of the European Academy (Academia Europaea) since 2013.

\section{Contact information:}

Institute of Linguistics RAS

1, B. Kislovskij per., Moscow, 125009, Russia

e-mail: aakibrik@gmail.com

ORCID: 0000-0002-3541-7637

\section{Сведения об авторе:}

Андрей Александрович КИБРИК - закончил МГУ имени М.В. Ломоносова в 1984 г. и с тех пор работает в Институте языкознания РАН. В настоящее время является директором Института, а также профессором МГУ. Его публикации посвящены таким проблемам, как язык и когнитивная система, устный и письменный дискурс, мультимодальность, языковое разнообразие, функционалистская теория языка, полевая лингвистика, жестовая лингвистика, коренные языки Америки (в особенности атабаскские), языки России, русская грамматика, языковая политика. С 2013 г. является членом Европейской академии (Academia Europaea).

\section{Контактная информация:}

Институт языкознания РАН,

Россия, 125009, Москва, Кисловский пер., 1

e-mail: aakibrik@gmail.com

ORCID: 0000-0002-3541-7637 